\title{
Composite beads of silica gel, alginate and poly(aspartic acid) for the immobilization of a lipase enzyme
}

\author{
E. Krisch ${ }^{1}$, D. Balogh-Weiser ${ }^{1,2}$, J. Klimkó $^{1}$, B. Gyarmati ${ }^{1}$, K. László $^{1}$, L. Poppe $^{2,3}$, A. Szilágyi ${ }^{1 *}$ \\ ${ }^{1}$ Department of Physical Chemistry and Materials Science, Faculty of Chemical Technology and Biotechnology, Budapest \\ University of Technology and Economics, Müegyetem rkp. 3., H-1111 Budapest, Hungary \\ ${ }^{2}$ Department of Organic Chemistry and Technology, Faculty of Chemical Technology and Biotechnology, Budapest \\ University of Technology and Economics, Müegyetem rkp. 3., H-1111 Budapest, Hungary \\ ${ }^{3}$ Biocatalysis and Biotransformation Research Centre, Faculty of Chemistry and Chemical Engineering, \\ Babeș-Bolyai University of Cluj-Napoca, Arany János str. 11., RO-400028 Cluj-Napoca, Romania
}

Received 16 August 2018; accepted in revised form 12 January 2019

\begin{abstract}
Silica gel/alginate/poly(aspartic acid) composite beads were prepared for immobilization of lipase B enzyme from Candida antarctica ( $\mathrm{CaLB}$ ). CaLB was first adsorbed on functionalized mesoporous silica gel particles, which were then entrapped in the interpenetrating network of thiolated poly(aspartic acid) and alginate, cross-linked by zinc ions. Finally, the beads were chemically stabilized by poly(ethylene glycol) diglycidyl ether, a bisepoxide cross-linker. In this manner, spherical biocatalysts with a diameter of 3-4 mm were prepared and their biocatalytic performance was tested by kinetic resolution of racemic 1-phenylethanol. The activity of $C a \mathrm{LB}$ in the beads was comparable to that of $C a \mathrm{LB}$ physically adsorbed on silica gel particles. The composite beads were easy to recover after use and no loss of biocatalytic activity was observed even after five test reaction cycles. Furthermore, the $C a \mathrm{LB}$ in the composite beads showed sufficient thermal stability up to $90^{\circ} \mathrm{C}$, contrary to $\mathrm{CaLB}$ adsorbed only on silica gel particles.
\end{abstract}

Keywords: polymer composites, biodegradable polymers, biocatalysis, enzyme, kinetic resolution

\section{Introduction}

The use of biocatalysis makes chemical reactions selective and environmentally friendly, but its industrial application is often hampered by the lack of longterm operational stability and difficult recovery and re-use of the enzymes. These drawbacks can be overcome by immobilizing of the enzymes. Conventional immobilization methods can be classified into three main groups, cross-linking, binding to a support (carrier) and entrapment (encapsulation) [1]. Cross-linked enzyme aggregates (CLEAs) or crystals (CLECs) are usually prepared in the absence of any carrier by a multifunctional cross-linker such as glutaraldehyde. Their advantages are improved specific and volumetric activity, but their use is limited by their poor mechanical properties $[2,3]$. The enzyme can be immobilized on the surface of a pre-fabricated solid support by physical or even chemical adsorption [4-6]. Typical supports for the enzyme immobilization include synthetic resins (e.g. porous polymer resins [7], such as the commercially available Novozym 435), biopolymers (e.g. chitosan [8, 9]) or inorganic solids (e.g. zeolite [10] or silica gel [11]). In the third approach the enzyme is entrapped within the organic or inorganic matrix, which requires the synthesis of the support in the presence of the enzyme [12]. To entrap enzymes usually either silica gel or polymers (most frequently poly(vinyl alcohol), PVA) [13-22] are used. Enzymes, such as lipase from Candida rugosa $[15,16]$, Pseudomonas aeruginosa [17], or amyloglucosidase 
from Aspergillus niger [14] have been entrapped in PVA matrices of different forms, including beads [13, 15, 17-19], microfibers [16, 20, 21] or films [14]. PVA beads are often synthesized with the aid of sodium alginate, while microfibers have been prepared via electrospinning. Although these PVA based beads possessed good mechanical strength and biocatalytic activity, PVA lacks functional groups that could be used for covalent entrapment of the enzymes in the polymer matrix. Physical entrapment of enzymes often results in leakage and activity loss because the size of the enzyme molecules is comparable to the pores of the support. Leakage can be avoided by increasing the molecular weight of the enzyme via cross-linking, although this usually decreases the enzymatic activity [23]. In composite immobilization protocols, amino-functionalized inorganic supports proved to be especially useful to form covalent bonds between enzymes (e.g. lipase from Candida rugosa) and the support [24, 25]. Formation of covalent bonds between the reactive functional groups of the support and the enzyme molecules could prove to be a better solution. To answer these challenges, a combination of different methods is needed.

Here, a combined method is proposed using surfacegrafted silica gel as solid support followed by entrapment in a polymer matrix and fixing by bisepoxide cross-linking for efficient immobilization of $\mathrm{Can}$ dida antarctica lipase $\mathrm{B}(\mathrm{Ca} \mathrm{LB})$. $\mathrm{Ca} \mathrm{LB}$ was selected due to its extensive utilization in organic syntheses as a biocatalyst, and also because $C a \mathrm{LB}$ is industrially relevant. Mesoporous silica gel particles were chosen for the physical adsorption of the enzyme molecules because a large surface area must be available for the bioactive molecules to achieve a high reaction rate. To ensure easy recovery and re-use, the particles should be embedded in larger beads, thereby facilitating the separation from the reaction mixture. Alginate (Alg) was used to form beads of regular shape. Finally, thiolated poly(aspartic acid) (PASP$\mathrm{SH})$ provided reactive groups for subsequent chemical stabilization. Poly(aspartic acid) (PASP) derivatives are advantageous in that they simply combine the benefits of synthetic polymers (e.g. well-defined molecular weight and structure $[26,27]$ ) and natural polymers (e.g. biocompatibility [28], biodegradability [29]). PASP derivatives can be synthesized from its precursor polymer, polysuccinimide, by using simple pathways [26, 30-33]. PASP-SH was chosen for the composite support because the concentration of reactive groups in the polymer matrix can be varied easily, while the activity of $C a \mathrm{LB}$ is expected to remain high, as conformational changes of the enzyme molecules are not limited due to the flexible structure of PASP. In addition, the presence of thiol groups enables us to establish covalent bonds with bisepoxide cross-linker molecules under mild reaction conditions, particularly at mild $\mathrm{pH}$ values, which is important for preserving the activity of entrapped enzyme molecules. Details of the synthesis and characterization of the chemical structure of the PASP-SH are described in our previous papers [31, 34].

Accordingly, the conventional enzyme immobilization techniques were combined consecutively (Figure 1). First, $C a \mathrm{LB}$ was adsorbed on the mesoporous silica gel support (gSG) that had previously been modified with aminopropyl and phenyl groups [35]. The silica gel particles with immobilized $C a \mathrm{LB}$ ( $\mathrm{Ca} \mathrm{LB} / \mathrm{gSG})$ were then dispersed in the aqueous solution of PASP-SH and sodium alginate (Alg). Spherical beads $(\mathrm{Ca} \mathrm{LB} / \mathrm{gSG} / \mathrm{Alg} / \mathrm{PASP}-\mathrm{SH})$ were formed with a diameter of a few $\mathrm{mm}$ by physical cross-linking of alginate with zinc ions. Finally, covalent bonds were established between the thiol groups of PASP$\mathrm{SH}$, the amine groups on the silica gel particles and/or the accessible nucleophilic groups (amine, thiol and hydroxyl groups) of $\mathrm{CaLB}$ using a bisepoxide crosslinker molecule to avoid leakage of the enzyme. The biocatalytic performance including biocatalytic activity, reusability and thermostability were investigated as a function of the $C a \mathrm{LB} / \mathrm{gSG}$ content of the $\mathrm{CaLB} / \mathrm{gSG} / \mathrm{Alg} / \mathrm{PASP}-\mathrm{SH}$ composite beads and the thiol content of PASP-SH. Kinetic resolution of racemic 1-phenylethanol was selected as a simple and robust model reaction to evaluate the biocatalytic performance of the biocatalysts in a stereoselective transesterification using an organic solvent.

\section{Experimental}

\subsection{Chemicals and reagents}

L-Aspartic acid (99\%), cysteamine (98\%) and dithiothreitol (DTT, 99\%) were purchased from Reanal (Hungary). Phosphoric acid (99\%) and dimethylformamide (DMF) were bought from Lach-Ner (Czech Republic). Poly(ethylene glycol) diglycidyl ether (PEGDE, $M_{\mathrm{n}}=500 \mathrm{~g} \cdot \mathrm{mol}^{-1}$ ), tris(hydroxymethyl) aminomethane (TRIS), racemic 1-phenylethanol (rac-1), vinyl acetate, $\mathrm{ZnCl}_{2}$ and sodium alginate (Alg) from brown algae were purchased from SigmaAldrich (Hungary). Imidazole was bought from 

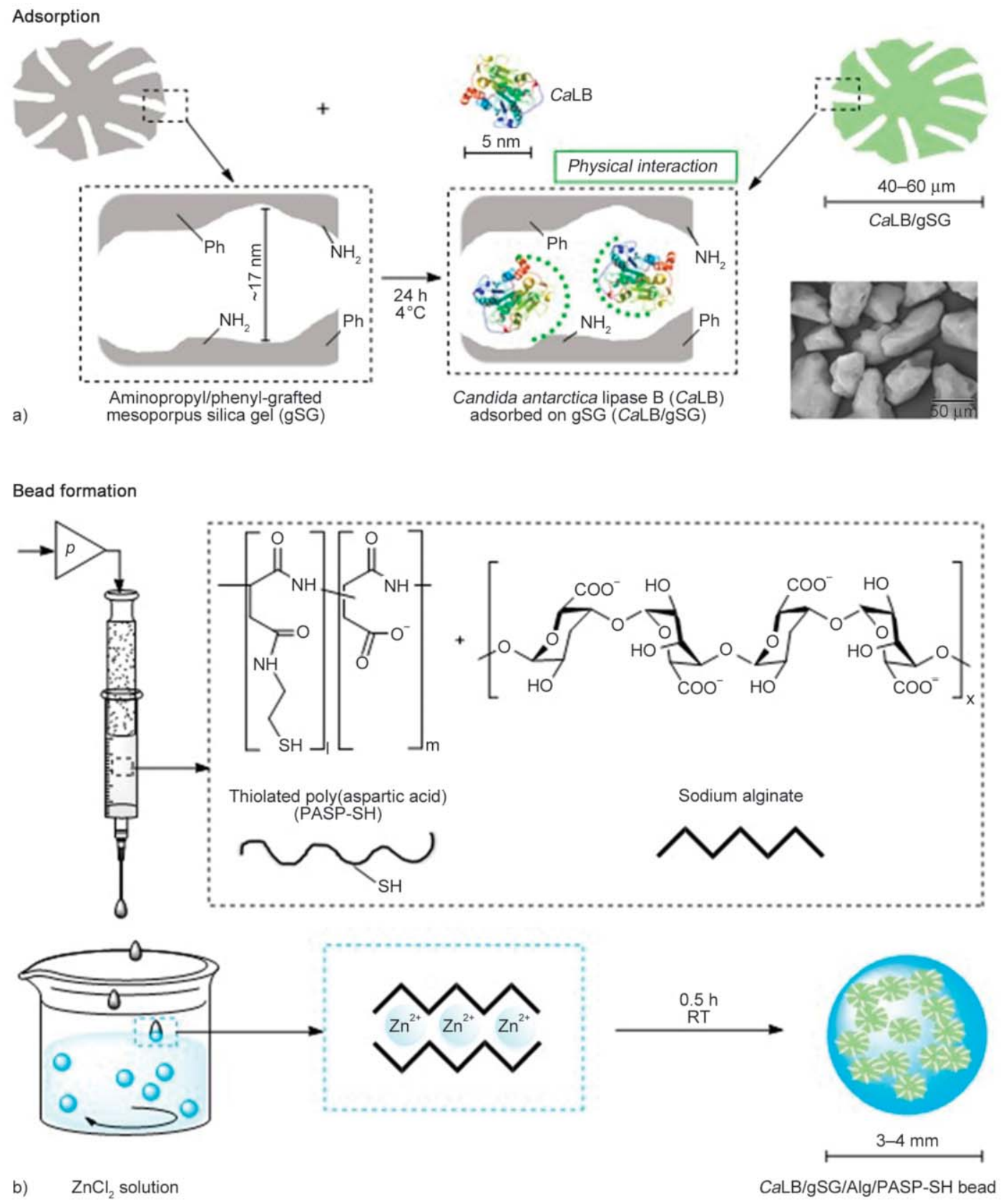

Chemical stabilization

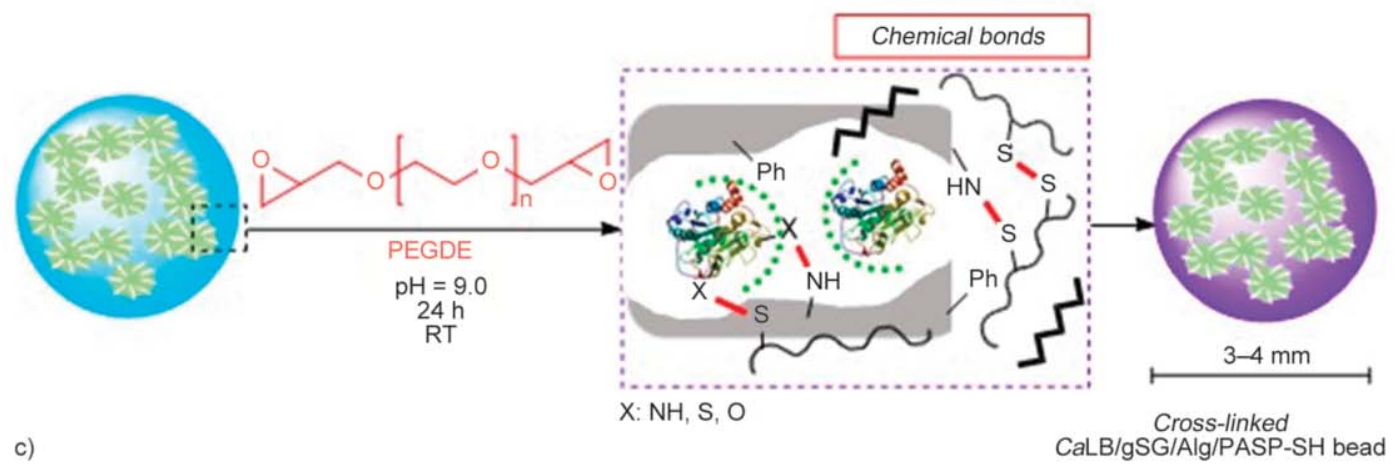

Figure 1. Immobilization of $\mathrm{CaLB}$ in cross-linked $\mathrm{CaLB} / \mathrm{gSG} / \mathrm{Alg} / \mathrm{PASP}-\mathrm{SH}$ composite beads: a) adsorption, b) bead formation and c) chemical stabilization. In the control samples the composite beads were not cross-linked with poly(ethylene glycol) diglycidyl ether (PEGDE), i.e., step 'c' was omitted. 
Acros Organics (Belgium). Aminopropyl/phenylgrafted (molar ratio: 1:3) mesoporous silica gel (irregular shape) was obtained from SynBiocat Ltd (Hungary). Candida antarctica lipase $\mathrm{B}(\mathrm{Ca} \mathrm{LB})$ as freeze dried powder was bought from c-LEcta $\mathrm{GmbH}$ (Germany). Organic solvents such as $n$-hexane, $t$-butyl methyl ether (MTBE) and 2-propanol were obtained from Merck (Hungary).

The imidazole buffer $(\mathrm{pH}=8.0 ; I=0.15 \mathrm{M})$ was prepared by dissolving $6.81 \mathrm{~g}$ imidazole and $10.39 \mathrm{~g}$ $\mathrm{KCl}$ in $1 \mathrm{dm}^{3}$ of water, and the $\mathrm{pH}$ was adjusted with $1 \mathrm{M} \mathrm{HCl}$. The phosphate buffered saline (PBS) solution of $\mathrm{pH}=7.4$ was prepared by dissolving $8.00 \mathrm{~g}$ of $\mathrm{NaCl}, 0.20 \mathrm{~g}$ of KCl, $1.44 \mathrm{~g}$ of $\mathrm{Na}_{2} \mathrm{HPO}_{4} \cdot 2 \mathrm{H}_{2} \mathrm{O}$ and $0.12 \mathrm{~g}$ of $\mathrm{KH}_{2} \mathrm{PO}_{4}$ in $1 \mathrm{dm}^{3}$ of water, the $\mathrm{pH}$ being adjusted with $0.1 \mathrm{M} \mathrm{HCl}$. The $\mathrm{pH}$ of the buffer solutions was checked with a Radelkis OP-271/1 $\mathrm{pH} /$ ion analyser. All reagents were used without further purification and their quality was 'for analysis' unless otherwise indicated. Ultrapure water $(\rho>$ 18.2 $\mathrm{M} \Omega \cdot \mathrm{cm}$, Millipore, USA) was used for the preparation of the aqueous solutions.

\subsection{Synthesis of thiolated poly(aspartic acid)}

Polysuccinimide (PSI), as the precursor polymer of thiolated poly(aspartic acid) (PASP-SH), was prepared by thermal polycondensation of L-aspartic acid, as reported earlier [36]. Briefly, $20.0 \mathrm{~g}$ of L-aspartic acid and $20.0 \mathrm{~g}$ of phosphoric acid was mixed in a $1 \mathrm{dm}^{3}$ boiling flask. The mixture was then heated in a rotary evaporator using silicone oil heating bath at $200^{\circ} \mathrm{C}$ and rotated at $180 \mathrm{rpm}$ for $7 \mathrm{~h}$ at $10 \mathrm{mbar}$. The resultant PSI was dissolved in $250 \mathrm{~cm}^{3}$ of DMF, then precipitated and washed with a large amount of water, then finally dried for 2 days at $40^{\circ} \mathrm{C}$. The yield of PSI was $95 \%$. The chemical structure of PSI was confirmed by ${ }^{1} \mathrm{H}$ NMR $\left(300 \mathrm{MHz}, \mathrm{DMSO}-d_{6}, \delta\right.$ : $5.12 \mathrm{ppm}\left(1 \mathrm{H}, \mathrm{CO}-\mathrm{CH}-\mathrm{CH}_{2}-\mathrm{CO}\right) ; 3.22 \mathrm{ppm}$ and $\left.2.74 \mathrm{ppm}\left(2 \mathrm{H}, \mathrm{CO}-\mathrm{CH}-\mathrm{CH}_{2}-\mathrm{CO}\right)\right)$. The molecular weight of the resulting PSI was $31.5 \mathrm{kDa}$ measured by a rolling ball viscometer (Anton Paar Lovis 2000 ME, solvent: $0.1 \mathrm{M} \mathrm{LiCl}$ in DMF, Mark-Houwink constants [37]: $a=0.76 ; K=1.32 \cdot 10^{-2}$ ).

To prepare PASP-SH [34], PSI was reacted with cysteamine $(0.1,0.3$ or 0.5 molar equivalents to the succinimide repeating units) in DMF under nitrogen atmosphere (ambient temperature, $72 \mathrm{~h}$ ). The reaction mixture was poured into ten-fold volume of buffer solution (imidazole, $\mathrm{pH}=8.0, I=0.15 \mathrm{M}$ ) and stirred for 3 days. Owing to the slightly alkaline environment,
Table 1. Theoretical $\left(\mathrm{X}_{\mathrm{SH}}\right)$ and calculated $\left(\mathrm{X}_{\mathrm{SH}, \mathrm{NMR}}\right)$ thiol content of PASP-SH.

\begin{tabular}{|l|c|c|}
\hline \multicolumn{1}{|c|}{ Polymer } & $\begin{array}{c}\mathbf{X}_{\mathbf{S H}} \\
{[\mathbf{m o l} \text { \%] }}\end{array}$ & $\begin{array}{c}\mathbf{X}_{\text {SH,NMR }} \\
{[\mathbf{m o l} \mathbf{0}]}\end{array}$ \\
\hline PASP-SH & \\
\hline PASP-SH & & 6.6 \\
\hline PASP-SH $_{50}$ & 10 & 25.5 \\
\hline
\end{tabular}

hydrolysis of the residual succinimide rings yielded PASP-SH. The PASP-SH was purified with dialysis against water (cut off: $\sim 13000 \mathrm{Da}, \mathrm{pH}$ was around 5.5) until the specific conductivity of water decreased below $10 \mu \mathrm{S} \cdot \mathrm{cm}^{-1}$, the solid PASP-SH was obtained by freeze drying. The resulting dry polymer was kept under argon and stored at $4{ }^{\circ} \mathrm{C}$. The chemical structure was confirmed by ${ }^{1} \mathrm{H}$ NMR $\left(300 \mathrm{MHz}, \mathrm{D}_{2} \mathrm{O}, \delta\right.$ : $4.58 \mathrm{ppm}\left(1 \mathrm{H}, \mathrm{CO}-\mathrm{CH}-\mathrm{CH}_{2}-\mathrm{CO}\right), 3.36 \mathrm{ppm}(2 \mathrm{H}$, $\left.\mathrm{NH}-\mathrm{CH}_{2}-\mathrm{CH}_{2}-\mathrm{SH}\right), \quad 2.81 \mathrm{ppm} \quad(2 \mathrm{H}$, $\left.\mathrm{CO}-\mathrm{CH}-\mathrm{CH}_{2}-\mathrm{CO}\right), \quad 2.64 \mathrm{ppm} \quad(2 \mathrm{H}$, $\left.\mathrm{NH}-\mathrm{CH}_{2}-\mathrm{CH}_{2}-\mathrm{SH}\right)$. The thiol contents was also determined by NMR spectroscopy $[31,34]$ and are shown in Table 1.

\subsection{Immobilization of $\mathrm{CaLB}$}

First, $C a \mathrm{LB}$ (4.0 g of freeze dried powder) was adsorbed from its solution in TRIS buffer $\left(500 \mathrm{~cm}^{3}\right.$, $100 \mathrm{mM}, \mathrm{pH}=7.5$ ) on silica gel grafted with aminopropyl and phenyl functions (gSG, $20.0 \mathrm{~g}$ ) according to our previous method [30], thus producing $\mathrm{Ca}$ LB adsorbed on $\mathrm{gSG}(\mathrm{CaLB} / \mathrm{gSG})$. Then, an aqueous suspension was prepared from PASP-SH, sodium alginate (30 and $5 \mathrm{wt} \%$, respectively) and $\mathrm{CaLB} / \mathrm{gSG}$ particles by strong mixing by magnetic stirrer (at $750 \mathrm{rpm}$ for $30 \mathrm{~min}$ at ambient temperature). Afterwards, the suspension $(3.0 \mathrm{~g})$ was added dropwise into the aqueous solution of $\mathrm{ZnCl}_{2}\left(200 \mathrm{~cm}^{3}, 24.5 \mathrm{~g} \cdot \mathrm{dm}^{-3}\right)$ by a syringe pump (flow rate $5 \mathrm{~cm}^{3} \cdot \mathrm{h}^{-1}$ ). The spherical beads formed were magnetically stirred ( $30 \mathrm{~min}$, at $250 \mathrm{rpm})$, then washed twice with water $\left(20 \mathrm{~cm}^{3}\right)$. The silica gel content of the composite beads varied between 36 and $85 \mathrm{wt} \%$, while the thiol content of PASP-SH ranged between 10 and $50 \%$.

Finally, the formed composite beads were shaken in an aqueous solution of PEGDE $\left(200 \mathrm{~cm}^{3}, 20 \mathrm{~g} \cdot \mathrm{dm}^{-3}\right.$ at $\mathrm{pH}=9.0$ adjusted with $1 \mathrm{M} \mathrm{NaOH}$, at ambient temperature) for $24 \mathrm{~h}$, then washed twice with water $\left(50 \mathrm{~cm}^{3}\right)$ and once with isopropyl alcohol $\left(20 \mathrm{~cm}^{3}\right)$. The resulting composite beads were dried in vacuum $(<1 \mathrm{mbar})$ at room temperature overnight and stored at $4{ }^{\circ} \mathrm{C}$ until further use. Composite beads not crosslinked with PEGDE were the control samples. 
Compositions of the synthesized biocatalysts are designated by the abbreviation as $\mathrm{CaLB} / \mathrm{gSG}_{\mathrm{X}} / \mathrm{Alg} /$ PASP-SH $\mathrm{SH}_{\mathrm{Y}}$ in the later sections of this study. Candida antarctica lipase $\mathrm{B}$ was adsorbed on grafted silica gel $(\mathrm{CaLB} / \mathrm{gSG})$, that was entrapped in the interpenetrating network of thiolated poly(aspartic acid) (PASP-SH) and alginate cross-linked by zinc ions (Alg). Finally, covalent bonds were established with PEGDE. The mass fraction of $\mathrm{CaLB} / \mathrm{gSG}(35,53$ or $70 \%$ ) is designated by $\mathrm{X}$ in the dried $\mathrm{CaLB} / \mathrm{gSG}_{\mathrm{X}} /$ $\mathrm{Alg} / \mathrm{PASP}-\mathrm{SH}_{\mathrm{Y}}$ beads, where $\mathrm{Y}$ is the thiol content of PASP-SH i.e., the feed ratio of the cysteamine to the repeating units of PSI $(10,30$ or $50 \%)$.

\subsection{Degree of swelling}

The degree of swelling $\left(Q_{\mathrm{V}}\right)$ is defined as the volume ratio of the swollen $\left(V_{\mathrm{S}}\right)$ to the dried composite beads $\left(V_{\mathrm{d}}\right)$. Vacuum dried $\left(4 \mathrm{~h}, 25^{\circ} \mathrm{C},<1 \mathrm{mbar}\right)$ composite beads were immersed in the mixture of hexane/ $\operatorname{MTBE}(2 / 1 \mathrm{~V} / \mathrm{V})$. After given times the diameter of the composite beads was measured with a calliper.

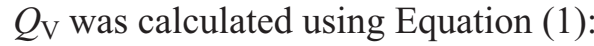

$Q_{\mathrm{V}}=\frac{V_{\mathrm{s}}}{V_{\mathrm{d}}}=\frac{d_{s}^{3}}{d_{\mathrm{d}}^{3}}$

The diameters of the swollen $\left(d_{\mathrm{s}}\right)$ and the dried $\left(d_{\mathrm{d}}\right)$ beads were the average of three measurements. The degree of swelling was calculated by using at least three beads.

\subsection{Morphological characterization (SEM and low temperature nitrogen adsorption)} The beads were analysed by JEOL JSM-5500LV (Japan) scanning electron microscope (SEM) in high vacuum at accelerating voltage of $20 \mathrm{kV}$. For better imaging the samples were coated with gold.

Nitrogen adsorption/desorption isotherms were measured at $-196^{\circ} \mathrm{C}$ with a Nova2000e (Quantachrome, USA) computer controlled apparatus. The apparent surface area $S_{\mathrm{BET}}$ was calculated using the BrunauerEmmett-Teller (BET) model. The total pore volume $V_{\text {tot }}$ was derived from the amount of vapour adsorbed at relative pressure $p / p_{0} \rightarrow 1$, assuming that the pores are filled with liquid adsorbate. The pore size distribution was derived by the BJH model. Transformation of all the primary adsorption data was performed by the Quantachrome software ASiQwin version 3.0.

\subsection{Kinetic resolution of racemic 1-phenylethanol}

The biocatalytic activity of the biocatalysts $(\mathrm{CaLB} /$ gSG or $C a \mathrm{LB} / \mathrm{gSG} / \mathrm{Alg} / \mathrm{PASP}-\mathrm{SH}$ beads) was studied in kinetic resolution of racemic 1-phenylethanol (rac-1). In a typical test, $\sim 10 \mathrm{mg}$ (the mass of one bead) were added to a sealed vial $\left(4 \mathrm{~cm}^{3}\right)$ containing hexane/MTBE $\left(1 \mathrm{~cm}^{3}, 2 / 1 \mathrm{~V} / \mathrm{V}\right)$, vinyl acetate $(90 \mu \mathrm{l})$ and $\mathrm{rac}-1(45 \mu \mathrm{l})$ and the resulting mixture was shaken at $40^{\circ} \mathrm{C}$. Samples $\left(50 \mu 1\right.$, diluted with $1 \mathrm{~cm}^{3}$ ethanol) from the reaction mixture were taken after $2 \mathrm{~h}$ and analysed by gas chromatography (GC).

The reaction mixtures were analysed on an Agilent 4890 GC (USA) instrument equipped with flame ionization detector (FID). A Hydrodex $\beta-6$ TBDM column [25 $\mathrm{m} \times 0.25 \mathrm{~mm}$, with a heptakis-(2,3-di-Omethyl-6- $O$ - $t$-butyl-dimethylsilyl)- $\beta$-cyclodextrin containing film of thickness $0.25 \mu \mathrm{m}$ ] was used for the separation at $120^{\circ} \mathrm{C}$. The injector and the FID were used at $250^{\circ} \mathrm{C}$, with $\mathrm{H}_{2}$ as carrier gas (head pressure $12 \mathrm{psi}$, split ratio 1:50). The area of the peaks $(A)$ at the retention times - $(S)$-1-phenylethyl acetate, $(S)$-2: $3.9 \mathrm{~min} ;(R)$-1-phenylethyl acetate, $(R)$-2: $4.3 \mathrm{~min} ;(R)$-1-phenylethanol, $(R)-1: 5.5 \mathrm{~min}$; $(S)$-1-phenylethanol, $(S)$-1: $5.8 \mathrm{~min}$ - were determined. The enantiomeric excess of the product $\left(e e_{(\mathrm{R})-2}\right)$ was calculated using Equation (2) [38]:

$e e_{(\mathrm{R})-2}=\frac{A_{(\mathrm{R})-2}-A_{(\mathrm{S})-2}}{A_{(\mathrm{R})-2}+A_{(\mathrm{S})-2}}$

The conversion of racemic substrate $(c)$ was calculated using Equation (3) [35], where $f$ is molar response factor (1.23):

$c=\frac{\frac{A_{(\mathrm{R})-2}+A_{(\mathrm{S})-2}}{f}}{\frac{A_{(\mathrm{R})-2}+A_{(\mathrm{S})-2}}{f}+A_{(\mathrm{R})-1}+A_{(\mathrm{S})-1}}$

The specific activity $\left(U_{\mathrm{B}}\left[\mu \mathrm{mol} \cdot \mathrm{min}^{-1} \cdot \mathrm{g}^{-1}\right]\right)$ and activity $\left(U\left[\mu \mathrm{mol} \cdot \mathrm{min}^{-1}\right]\right)$ of the biocatalyst were calculated from Equation (4) and (5), respectively [35]:

$U_{\mathrm{B}}=\frac{n_{r a c-1} \cdot c}{t \cdot m_{\mathrm{B}}}$
$U=\frac{n_{r a c-1} \cdot c}{t}$

where $n_{r a c-1}[\mu \mathrm{mol}]$ is the amount of racemic 1-phenylethanol, $t$ [min] is the reaction time and $m_{\mathrm{B}}$ $[\mathrm{g}]$ is the total mass of the biocatalyst. 


\subsection{Stability of the biocatalysts}

The reusability of the biocatalysts was investigated in consecutive tests of biocatalytic activity as described in Section 2.6. After each cycle (one cycle lasted $20 \mathrm{~h}$, samples being taken after $6 \mathrm{~h}$ ), the biocatalyst was removed from the reaction mixture by centrifugation $\left(2200 \mathrm{~g}, 15 \mathrm{~min}, 8^{\circ} \mathrm{C}, \mathrm{CaLB} / \mathrm{gSG}\right)$ or by decantation ( $\mathrm{CaLB} / \mathrm{gSG} / \mathrm{Alg} / \mathrm{PASP}-\mathrm{SH}$ beads), the supernatant was decanted and the residual biocatalyst was washed twice with hexane and dried for $4 \mathrm{~h}$ under vacuum $\left(25^{\circ} \mathrm{C},<1 \mathrm{mbar}\right)$. Afterwards, the biocatalyst was added to fresh reaction medium and the reaction was repeated under the same conditions. The activity of the biocatalysts was determined after each run.

To test the stability of the biocatalysts at different pretreatment temperatures, the samples $(\sim 10 \mathrm{mg})$ were placed in $1 \mathrm{~cm}^{3}$ of toluene and kept in an oil bath at constant temperature for $16 \mathrm{~h}$ (at 50, 60, 70, 80 or $90^{\circ} \mathrm{C}$ ). Afterwards, the specific activity of the biocatalysts was measured according to Section 2.6.

\section{Results and discussion}

Our goal was to immobilize Candida antarctica lipase $\mathrm{B}(\mathrm{Ca} \mathrm{LB})$ enzyme in a solid composite matrix in order to obtain good catalytic activity, reusability and thermal stability. A combination of different immobilization methods was used. $C a$ LB was first physically adsorbed on the aminopropyl and phenyl grafted mesoporous silica gel support of high surface area $\left(280 \mathrm{~m}^{2} \cdot \mathrm{g}^{-1}\right)$. Functionalised mesoporous silica gel particles were able to adsorb enzymes and our previous study indicated that the presence of phenyl and aminopropyl groups provided strong interactions with the functional groups of $\mathrm{CaLB}$ [30]. Silica gel particles visualized with SEM were found to have irregular shapes with particle sizes of around 40 $60 \mu \mathrm{m}$. The enzyme decoration slightly reduced the surface area $\left(250 \mathrm{~m}^{2} \cdot \mathrm{g}^{-1}\right)$. The desorption branch of the isotherm was used to calculate the pore size distribution, as the isotherm had a H1 type hysteresis loop [39]. The pore size distribution showed a single narrow peak with a maximum at $17 \mathrm{~nm}$.

Next, $C a \mathrm{LB} / \mathrm{gSG}$ particles were dispersed in the aqueous solution of thiolated PASP and sodium alginate. Sodium alginate was applied to obtain beads of regular shape and controlled size, whereas the thiolated PASP had a key role in the physical entrapment and chemical immobilization of the $C a \mathrm{LB} / \mathrm{gSG}$ particles. The precursor suspension was added dropwise into $\mathrm{ZnCl}_{2}$ solution. Due to replacement of the monovalent $\mathrm{Na}^{+}$of alginate by divalent $\mathrm{Zn}^{2+}$ ions, an interpenetrating network was formed almost instantaneously. Based on pre-experiments, which focused on the shape and the mechanical integrity of the beads, the mass ratio of sodium alginate to PASP$\mathrm{SH}[\mathrm{wt} \%]$ in the composite beads was chosen to be 1:6 to yield uniform spherical beads in $\mathrm{ZnCl}_{2}$ solution. Chemical links were formed by the addition of bifunctional PEGDE. The epoxy groups of the crosslinker can react easily with the thiol groups of PASP$\mathrm{SH}$, the amine groups of the silica gel particles and the functional groups of $\mathrm{CaLB}\left(-\mathrm{NH}_{2},-\mathrm{SH},-\mathrm{OH}\right)$, which ensures stability for the biocatalyst through chemical interactions.

The properties of composite beads were investigated as a function of $C a \mathrm{LB} / \mathrm{gSG}$ content (the mass fraction of $C a \mathrm{LB} / \mathrm{gSG}$ in the dried $C a \mathrm{LB} / \mathrm{gSG} / \mathrm{Alg} /$ PASP-SH beads varied between 36 and $85 \mathrm{wt} \%$ ) and the thiol content of PASP-SH (10, 30 and $50 \mathrm{~mol} \%$ ). The beads, regardless of the composition, were uniformly shaped spherical beads of diameter around 3-4 mm (Figure 2).

Control samples were prepared without PEGDE to demonstrate the role of chemical immobilization. The control samples were expected to dissolve in the presence of excess $\mathrm{Na}^{+}$ions, due to re-formation of watersoluble sodium alginate polymer chains as a result of disruption of physical cross-links of alginate by $\mathrm{Zn}^{2+}$ ions. Both the control samples and the composite beads with chemical linkages were shaken for one day in PBS, and, as expected, the control samples disintegrated, while the beads with chemical linkages

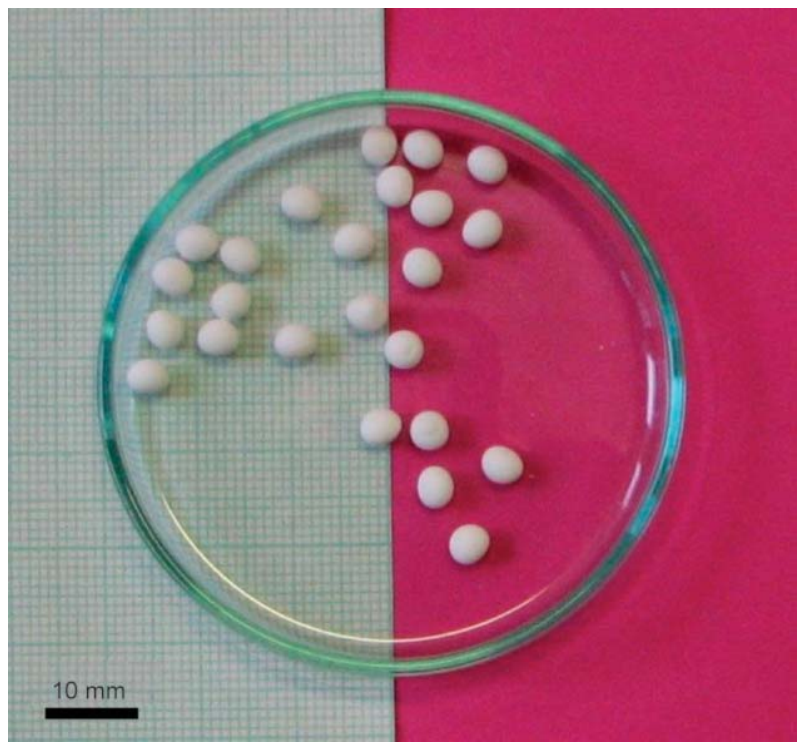

Figure 2. $\mathrm{CaLB} / \mathrm{gSG}_{53} / \mathrm{Alg} / \mathrm{PASP}-\mathrm{SH}_{50}$ composite beads. 
kept their original size and shape. The experiment proved that chemical cross-linking is a key step in the formation and stabilization of the $C a \mathrm{LB} / \mathrm{gSG} /$ Alg/PASP-SH beads.

The swelling properties of the biocatalyst are important if they are used as filling materials, e.g. for columns in flow reactors. Swelling of the biocatalyst used in a flow reactor can hinder the continuous stream of the eluent by narrowing the microchannels

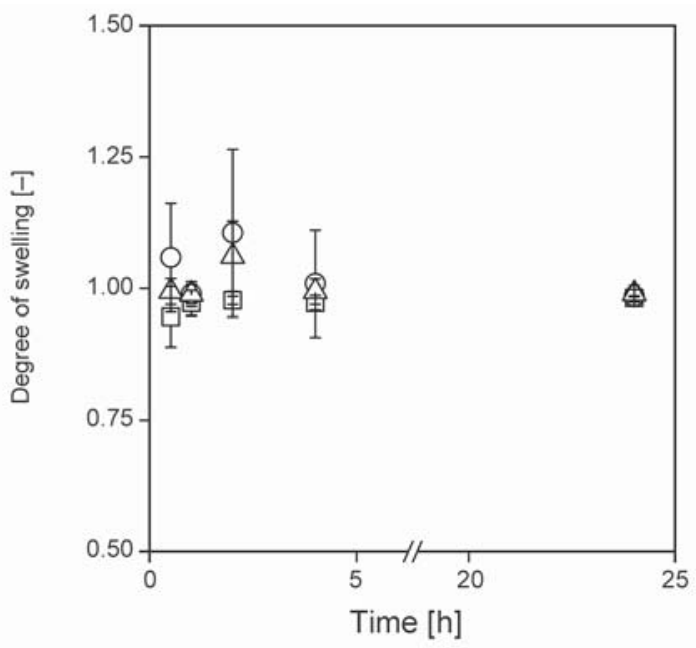

Figure 3. Degree of swelling of the $\mathrm{CaLB} / \mathrm{gSG}_{53} / \mathrm{Alg} / \mathrm{PASP}-$ $\mathrm{SH}_{\mathrm{Y}}$ composite beads as a function of time in the mixture of hexane and MTBE in the volume ratio 2:1 ( $\mathrm{CaLB} / \mathrm{gSG}_{53} / \mathrm{Alg} / \mathrm{PASP}-\mathrm{SH}_{10}$ : squares (口), $\mathrm{CaLB} / \mathrm{gSG}_{53} / \mathrm{Alg} / \mathrm{PASP}-\mathrm{SH}_{30}$ : circles (O), $\mathrm{CaLB} / \mathrm{gSG}_{53} / \mathrm{Alg} / \mathrm{PASP}_{-\mathrm{SH}_{50}}$ : triangles $\left.(\triangle)\right)$. or even plugging the column. The degree of swelling of the $\mathrm{CaLB} / \mathrm{gSG}_{53} / \mathrm{Alg} / \mathrm{PASP}-\mathrm{SH}_{\mathrm{Y}}$ cross-linked composite beads was studied in the mixture of hexane and MTBE in the volume ratio 2:1 (this mixture was used in the evaluation of biocatalytic performance). The degree of swelling was almost constant over the whole experiment and was approximately 1.0. Thus we can conclude that $\mathrm{CaLB} / \mathrm{gSG}_{53} / \mathrm{Alg} / \mathrm{PASP}-\mathrm{SH}_{\mathrm{Y}}$ composite beads do not swell in the chosen solvent mixture (Figure 3 ) and they can be conveniently stored in their dried state prior to use. The small deviation of diameter values proves the spherical shape of the beads. Composite beads preserved their mechanical integrity throughout the experiment.

SEM images were taken of the surface (Figure 4a$4 c$ ) and the cross-section (Figure 4d-4f) of the composite beads at different magnifications. Since silica gel particles can be clearly seen on the cross-sectional images, we may conclude that silica gel particles with $40-60 \mu \mathrm{m}$ are successfully embedded into the polymer matrix of the composite beads. Furthermore, free volume among the silica gel particles can be observed (Figure 4f). This structure facilitates diffusion of the substrate to the enzyme molecules.

$\mathrm{Ca} \mathrm{LB} / \mathrm{gSG} / \mathrm{Alg} / \mathrm{PASP}-\mathrm{SH}$ composite beads were studied as enantiomer-selective biocatalysts in the enzymatic resolution of racemic 1-phenylethanol (rac-1) by vinyl acetate in hexane/MTBE (Figure 5).

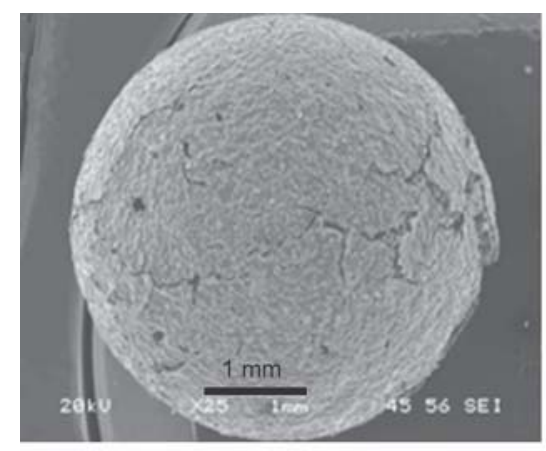

a)

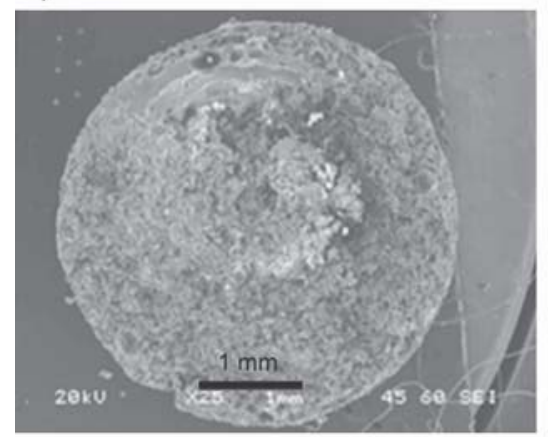

d)

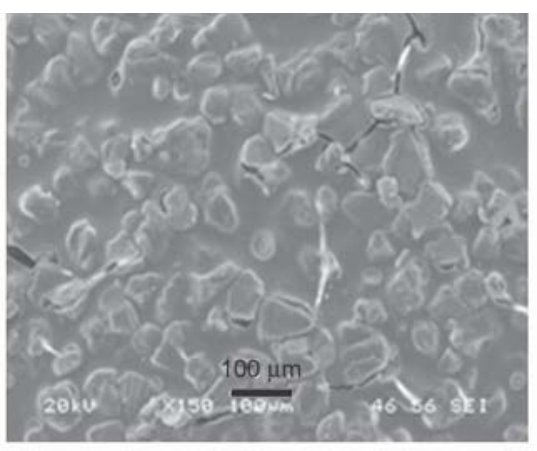

b)

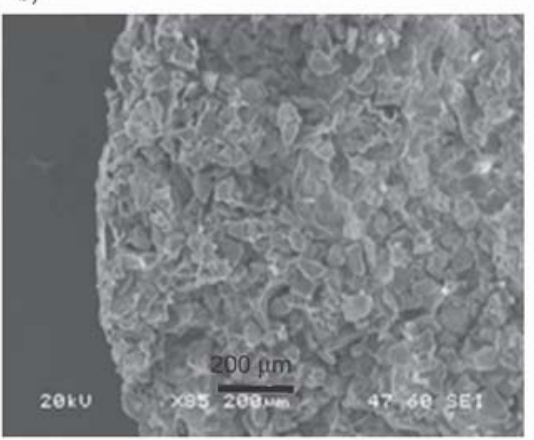

e)

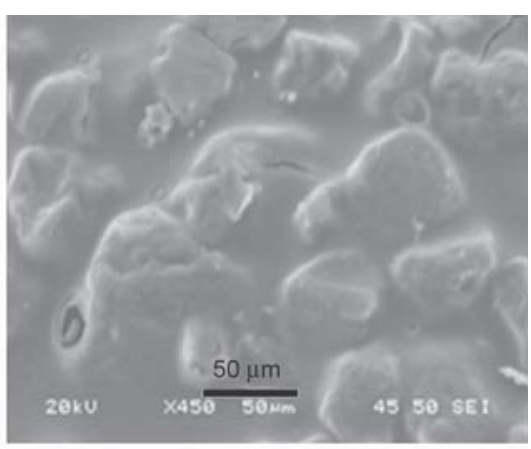

c)

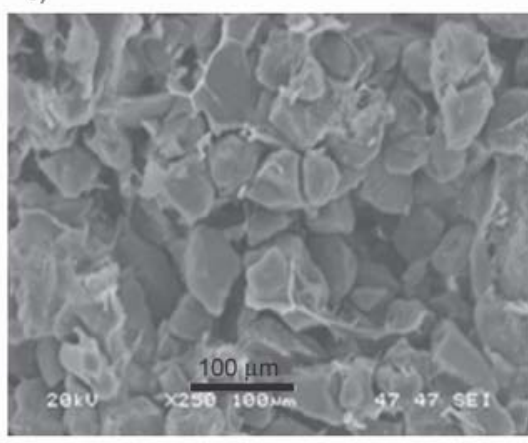

f)

Figure 4. Morphology of the $\mathrm{CaLB} / \mathrm{gSG}_{53} / \mathrm{Alg} / \mathrm{PASP}-\mathrm{SH}_{50}$ bead, $(\mathrm{a}-\mathrm{c})$ the surface and $(\mathrm{d}-\mathrm{f})$ the cross-section of the bead at different magnifications. 


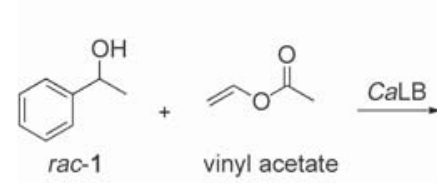

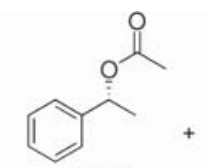

(R)-2

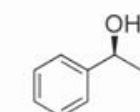

(S)-1
Figure 5. $\mathrm{CaLB}$ catalysed kinetic resolution of racemic 1-phenylethanol (rac-1) to $(R)$-1-phenylethyl acetate $[(R)-2]$ and $(S)$-1-phenylethanol $[(S)-\mathbf{1}]$.

Catalytic properties, such as enantiomeric excess (ee), conversion $(c)$ and biocatalytic activity (activity, $U$ or specific activity, $U_{\mathrm{B}}$ ) of the prepared biocatalysts were compared to determine the effect of thiol content of PASP-SH and $\mathrm{CaLB} / \mathrm{gSG}$ content of the beads on catalytic performance.

Specific activity $\left(U_{\mathrm{B}}\right)$ of $\mathrm{CaLB} / \mathrm{gSG} / \mathrm{Alg} / \mathrm{PASP}-\mathrm{SH}$ composite beads is shown in Figure 6. The specific activity of composite beads without chemical crosslinking (control samples, hatched columns) is significantly lower than those of cross-linked composite beads (plain columns). The most likely reason for this phenomenon could be that the $\mathrm{CaLB} / \mathrm{gSG}$ particles were washed out from the polymer matrix due to absence of covalent bonds. The huge difference in the activities of the control samples and the cross-linked composite beads confirms the necessity of chemical cross-links in the $\mathrm{CaLB} / \mathrm{gSG} / \mathrm{Alg} / \mathrm{PASP}-\mathrm{SH}$ composite beads. The specific activity of the composite beads increased largely with increasing $\mathrm{Ca} \mathrm{LB} / \mathrm{gSG}$ content, due to increasing enzyme content. The thiol content of PASP-SH, however, seems to have a less significant effect on the catalytic performance. In some cases, the specific activity of the composite beads approached, or even surpassed, the specific activity of the non-entrapped $\mathrm{CaLB} / \mathrm{gSG}$ particles (crossed column), despite the fact that the enzyme content was lower in the beads and the polymer matrix partially hindered the substrate diffusion. This suggests the importance of chemical interactions with the polymer matrix, which may help to keep the active tertiary structure of the enzyme. Enantiomeric excess $\left(e e_{(R)-2}\right)$ of the product was $>99 \%$ in all experiments. A conversion between $10 \%$ (lowest $\mathrm{CaLB} /$ gSG content) and $25 \%$ (highest $\mathrm{CaLB} / \mathrm{gSG}$ content) was achieved at the reaction time of two hours.

The reusability of biocatalysts is a key parameter in both environmental and economic aspects. The composite beads were tested in five consecutive cycles to follow the change in their catalytic performance. Although the cross-linked $\mathrm{CaLB} / \mathrm{gSG} / \mathrm{Alg} / \mathrm{PASP}-\mathrm{SH}$ composite beads with higher $C a \mathrm{LB} / \mathrm{gSG}$ content
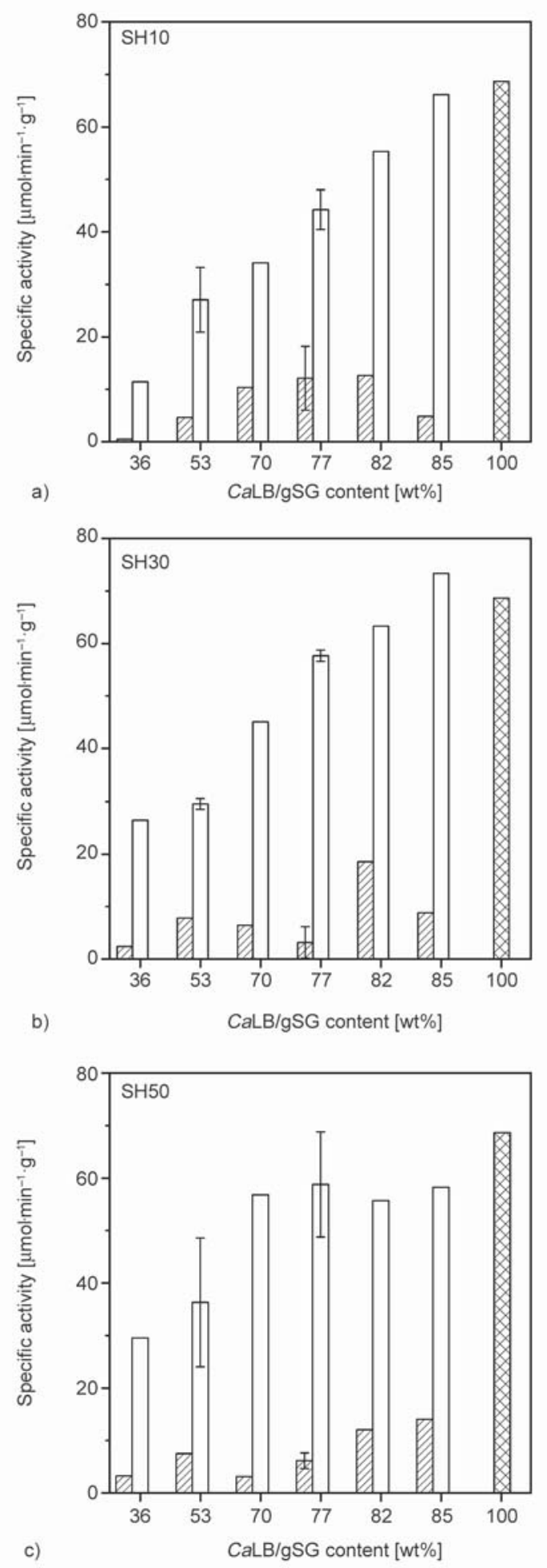

Figure 6. Comparison of specific activity $\left(U_{\mathrm{B}}\right)$ of $C a \mathrm{LB}$ ad-

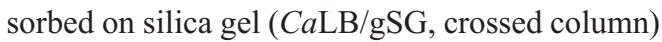
with $\mathrm{CaLB}$ entrapped in $\mathrm{CaLB} / \mathrm{gSG} / \mathrm{Alg} / \mathrm{PASP}-\mathrm{SH}$ beads cross-linked with PEGDE (plain columns) or without cross-linking (hatched columns) in the kinetic resolution of racemic 1-phenylethanol (rac-1) at different compositions:

a) $\mathrm{CaLB} / \mathrm{gSG}_{\mathrm{X}} / \mathrm{Alg} / \mathrm{PASP}-\mathrm{SH}_{10}$;

b) $\mathrm{CaLB} / \mathrm{gSG}_{\mathrm{X}} / \mathrm{Alg} / \mathrm{PASP}-\mathrm{SH}_{30}$;

c) $\mathrm{Ca} \mathrm{LB} / \mathrm{gSG}_{\mathrm{X}} / \mathrm{Alg} / \mathrm{PASP}-\mathrm{SH}_{50}$. 
showed larger biocatalytic activity, the composite beads with $70 \mathrm{wt} \%$ or more $C a \mathrm{LB} / \mathrm{gSG}$ content disintegrated during the second cycle in the reusability test. The composite beads with $\mathrm{CaLB} / \mathrm{gSG}$ content of 36 and $53 \mathrm{wt} \%$ were mechanically stable, and the reusability tests were carried out with the samples showing better activity $(\mathrm{Ca} \mathrm{LB} / \mathrm{gSG}$ content of $53 \mathrm{wt} \%$ ). In the context of reusability the most important property is the activity $(U)$ of the biocatalyst, which depends on the mass of the biocatalyst recovered after the cycles. Activities of the $\mathrm{Ca \textrm {LB }} / \mathrm{gSG}_{53} /$ Alg/PASP-SHY composite beads after the different cycles are shown in Figure 7a. While activity of the composite beads remains almost the same even after five cycles, silica gel particles exhibit a significant decrease in their activity. The relatively low activity of $\mathrm{Ca \textrm {LB }} / \mathrm{gSG}_{53} / \mathrm{Alg} / \mathrm{PASP}-\mathrm{SH}_{10}$ in the first cycle can be explained by the residual water left in the beads after drying. In organic media the residual water can reduce the activity of the lipase [40]. Due to poor recoverability, the decreasing activity of $\mathrm{Ca} \mathrm{LB} / \mathrm{gSG}$ is caused primarily by the significant mass loss (Figure 7b). By contrast, the composite beads of diameter around 3-4 mm could be recovered completely due to their easy-to-handle form and only negligible mass loss was observed.

The stability at different pretreatment temperatures of the $C a \mathrm{LB} / \mathrm{gSG}_{53} / \mathrm{Alg} / \mathrm{PASP}-\mathrm{SH}_{\mathrm{Y}}$ composite beads with different thiol content of PASP-SH (10, 30 and $50 \%$ ) and that of $\mathrm{Ca} \mathrm{LB} / \mathrm{gSG}$ were tested. The specific activity $\left(U_{\mathrm{B}}\right)$ was calculated to show the potential

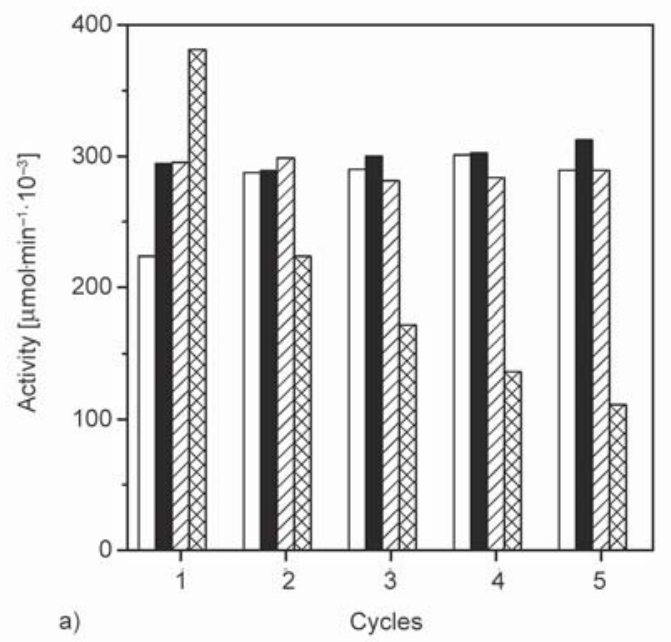

activity loss due to denaturation of the enzyme upon heating. The biocatalysts were kept in toluene at a certain temperature $\left(40-90^{\circ} \mathrm{C}\right)$ for $16 \mathrm{~h}$ and then their specific activity was determined and compared to the value of $U_{\mathrm{B}}$ after storage at $40^{\circ} \mathrm{C}$ (relative spe-

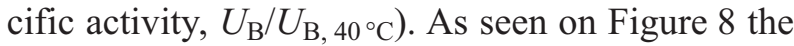
composite beads suffered only slight loss in activity upon heating in contrast to the $C a \mathrm{LB} / \mathrm{gSG}$ biocatalyst. The polymer network may better preserve the active structure of the enzyme through the first order interactions.

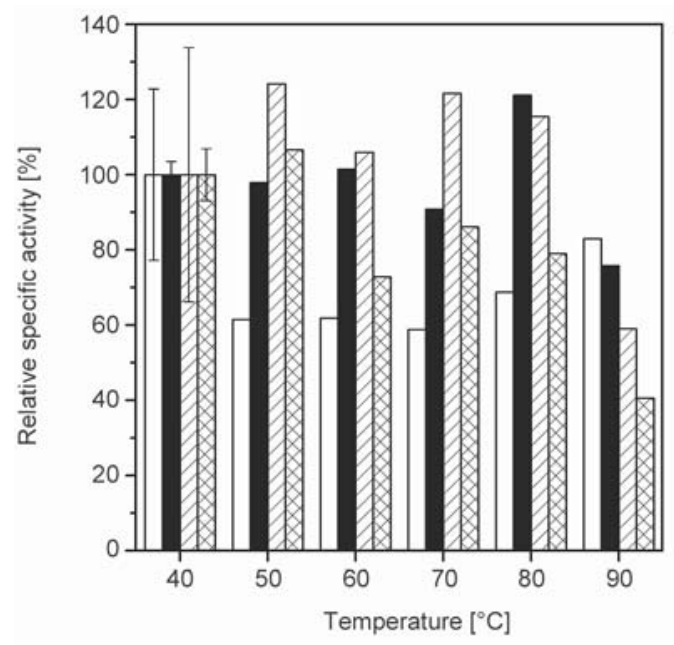

Figure 8. Change in the relative specific activity $\left(U_{\mathrm{B}} / U_{\left.\mathrm{B}, 40^{\circ} \mathrm{C}\right)}\right.$ of the biocatalysts as a function of the temperature of pre-treatment of $16 \mathrm{~h},\left(\mathrm{CaLB} / \mathrm{gSG}_{53} / \mathrm{Alg} / \mathrm{PASP}-\right.$ $\mathrm{SH}_{10}$ : plain columns, $\mathrm{CaLB} / \mathrm{gSG}_{53} / \mathrm{Alg} / \mathrm{PASP}-\mathrm{SH}_{30}$ : black columns, $\mathrm{CaLB} / \mathrm{gSG}_{53} / \mathrm{Alg} / \mathrm{PASP}-\mathrm{SH}_{50}$ : hatched columns and $\mathrm{CaLB} / \mathrm{gSG}$ : crossed columns).

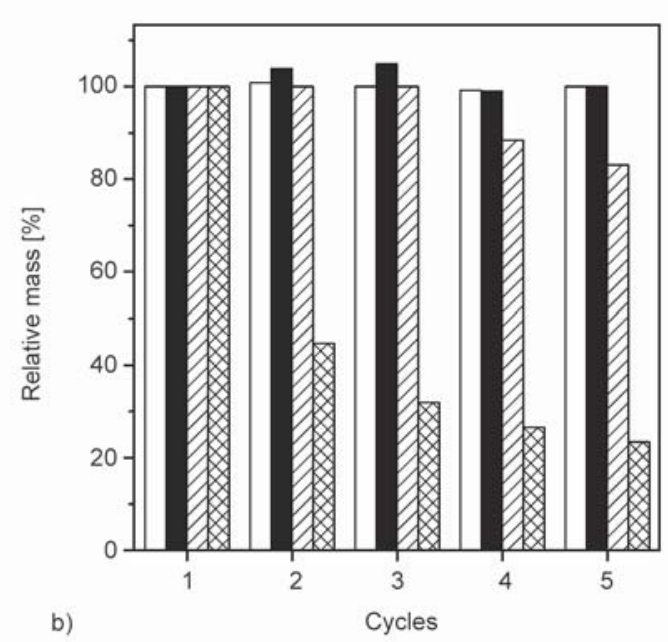

Figure 7. a) Activity $(U)$ and b) relative mass of the cross-linked composite beads with different thiol content of PASP-SH and the $\mathrm{CaLB} / \mathrm{gSG}$ particles in consecutive cycles of reactions $\left(\mathrm{Ca} \mathrm{LB} / \mathrm{gSG}_{53} / \mathrm{Alg} / \mathrm{PASP}-\mathrm{SH}_{10}\right.$ : plain columns, $\mathrm{CaLB} / \mathrm{gSG}_{53} / \mathrm{Alg} / \mathrm{PASP}-\mathrm{SH}_{30}$ : black columns, $\mathrm{CaLB} / \mathrm{gSG}_{53} / \mathrm{Alg} / \mathrm{PASP}-\mathrm{SH}_{50}$ : hatched columns and $\mathrm{CaLB} / \mathrm{gSG}$ particles: crossed columns). 


\section{Conclusions}

A method was developed for the immobilization of Candida antarctica lipase B (CaLB) by the entrapment of $C a$ LB loaded silica gel particles in a polymer matrix. $C a \mathrm{LB}$ was first adsorbed into aminopropyl/phenyl grafted mesoporous silica gel (gSG) followed by the entrapment of the enzyme-loaded particles in the interpenetrating network of thiolated poly(aspartic acid) (PASP-SH) and sodium alginate cross-linked by $\mathrm{Zn}^{2+}$ ions to obtain spherical beads. Finally, the enzyme and the particles were stabilized by covalent cross-linking with a bisepoxide crosslinker, poly(ethylene glycol) diglycidyl ether, which established chemical bonds between the thiol groups of PASP-SH, the amine groups on the silica gel particles and the functional groups of the $C a \mathrm{LB}$. The biocatalysts developed were tested in the kinetic resolution of racemic 1-phenylethanol. Despite of the diffusion path length and the covalent immobilization the biocatalytic activity of the enzyme in the $\mathrm{Ca} \mathrm{LB} / \mathrm{gSG} / \mathrm{Alg} / \mathrm{PASP}-\mathrm{SH}$ beads did not decrease and approached that of the non-entrapped $\mathrm{Ca} \mathrm{LB} / \mathrm{gSG}$. Furthermore, the $\mathrm{CaLB} / \mathrm{gSG} / \mathrm{Alg} / \mathrm{PASP}-\mathrm{SH}$ beads (3-4 $\mathrm{mm}$ ) were easy to recover from the reaction mixture, in contrast to the $C a \mathrm{LB} / \mathrm{gSG}$ particles (40$60 \mu \mathrm{m})$. The $C a \mathrm{LB} / \mathrm{gSG} / \mathrm{Alg} / \mathrm{PASP}-\mathrm{SH}$ composite beads, contrary to the $\mathrm{CaLB} / \mathrm{gSG}$ particles, did not suffer considerable activity loss even after five cycles of test reaction. In addition, the biocatalytic activity of the $C a \mathrm{LB} / \mathrm{gSG} / \mathrm{Alg} / \mathrm{PASP}-\mathrm{SH}$ composite beads was stable up to $90^{\circ} \mathrm{C}$. These results indicate the potential application of this formulation of $\mathrm{Ca} \mathrm{LB}$ as a biocatalyst on laboratory or even on an industrial scale. The applied immobilization process deserves further investigations for possible utilization in continuous processes and in scaling-up and for the general applicability with other enzymes.

\section{Acknowledgements}

This research was supported by the National Research, Development and Innovation Office (NKFIH FK 125074) and by the Higher Education Excellence Program of the Ministry of Human Capacities in the frame of Biotechnology research area of Budapest University of Technology and Economics (BME FIKP-BIO). B. Gyarmati acknowledges the financial support of the János Bolyai Research Scholarship of the Hungarian Academy of Sciences. A. Szilágyi is grateful for the support of the ÚNKP-17-4-III New National Excellence Program of the Ministry of Human Capacities.

\section{References}

[1] Sheldon R. A.: Enzyme immobilization: The quest for optimum performance. Advanced Synthesis and Catalysis, 349, 1289-1307 (2007).

https://doi.org/10.1002/adsc.200700082

[2] Sheldon R. A.: Characteristic features and biotechnological applications of cross-linked enzyme aggregates (CLEAs). Applied Microbiology and Biotechnology, 92, 467-477 (2011). https://doi.org/10.1007/s00253-011-3554-2

[3] Cui J. D., Jia S. R.: Optimization protocols and improved strategies of cross-linked enzyme aggregates technology: Current development and future challenges. Critical Reviews in Biotechnology, 35, 15-28 (2015). https://doi.org/10.3109/07388551.2013.795516

[4] Zucca P., Sanjust E.: Inorganic materials as supports for covalent enzyme immobilization: Methods and mechanisms. Molecules, 19, 14139-14194 (2014). https://doi.org/10.3390/molecules190914139

[5] Mohamad N. R., Marzuki N. H. C., Buang N. A., Huyop F., Wahab R. A.: An overview of technologies for immobilization of enzymes and surface analysis techniques for immobilized enzymes. Biotechnology, Biotechnological Equipment, 29, 205-220 (2015). https://doi.org/10.1080/13102818.2015.1008192

[6] Minteer S. D.: Enzyme stabilization and immobilization-Methods and protocols. Springer, New York (2017).

[7] Cantone S., Ferrario V., Corici L., Ebert C., Fattor D., Spizzo P., Gardossi L.: Efficient immobilisation of industrial biocatalysts: Criteria and constraints for the selection of organic polymeric carriers and immobilisation methods. Chemical Society Reviews, 42, 62626276 (2013). https://doi.org/10.1039/C3CS35464D

[8] Mendes A. A., de Castro H. F., Andrade G. S. S., Tardioli P. W., Giordano R. de L. C.: Preparation and application of epoxy-chitosan/alginate support in the immobilization of microbial lipases by covalent attachment. Reactive and Functional Polymers, 73, 160-167 (2013). https://doi.org/10.1016/j.reactfunctpolym.2012.08.023

[9] Krajewska B.: Application of chitin- and chitosan-based materials for enzyme immobilizations: A review. Enzyme and Microbial Technology, 35, 126-139 (2004). https://doi.org/10.1016/j.enzmictec.2003.12.013

[10] Liu B., Hu R., Deng J.: Characterization of immobilization of an enzyme in a modified $Y$ zeolite matrix and its application to an amperometric glucose biosensor. Analytical Chemistry, 69, 2343-2348 (1997). https://doi.org/10.1021/ac960930u

[11] Hartmann M., Kostrov X.: Immobilization of enzymes on porous silicas - Benefits and challenges. Chemical Society Reviews, 42, 6277-6289 (2013). https://doi.org/10.1039/C3CS60021A

[12] Datta S., Christena L. R., Rajaram Y. R. S.: Enzyme immobilization: An overview on techniques and support materials. 3 Biotech, 3, 1-9 (2013). https://doi.org/10.1007/s13205-012-0071-7 
[13] Nunes M. A. P., Vila-Real H., Fernandes P. C. B., Ribeiro M. H. L.: Immobilization of naringinase in PVA-alginate matrix using an innovative technique. Applied Biochemistry and Biotechnology, 160, 2129-2147 (2010). https://doi.org/10.1007/s12010-009-8733-6

[14] Uhlich T., Ulbricht M., Tomaschewski G.: Immobilization of enzymes in photochemically cross-linked polyvinyl alcohol. Enzyme and Microbial Technology, 19, 124-131 (1996). https://doi.org/10.1016/0141-0229(95)00190-5

[15] Dave R., Madamwar D.: Esterification in organic solvents by lipase immobilized in polymer of PVA-alginate-boric acid. Process Biochemistry, 41, 951-955 (2006).

https://doi.org/10.1016/j.procbio.2005.10.019

[16] Wang Y., Hsieh Y-L.: Immobilization of lipase enzyme in polyvinyl alcohol (PVA) nanofibrous membranes. Journal of Membrane Science, 309, 73-81 (2008). https://doi.org/10.1016/j.memsci.2007.10.008

[17] Pang Y., Zeng G-M., Tang L., Zhang Y., Liu Y-Y., Lei X-X., Wu M-S., Li Z., Liu C.: Cr(VI) reduction by Pseudomonas aeruginosa immobilized in a polyvinyl alcohol/sodium alginate matrix containing multi-walled carbon nanotubes. Bioresource Technology, 102, 1073310736 (2011). https://doi.org/10.1016/j.biortech.2011.08.078

[18] Zain N. A. M., Suhaimi M. S., Idris A.: Development and modification of PVA-alginate as a suitable immobilization matrix. Process Biochemistry, 46, 2122-2129 (2011). https://doi.org/10.1016/j.procbio.2011.08.010

[19] Cruz-Ortiz B. R., Ríos-González L. J.: Influence of the reaction parameters on biodiesel production catalyzed by a lipase from Thermomyces lanuginosus immobilized in PVA-alginate beads. Energy Sources Part A: Recovery, Utilization, and Environmental Effects, 39, 2127-2132 (2017).

https://doi.org/10.1080/15567036.2014.986590

[20] Wu C. M., Yu S. A., Lin S. L.: Graphene modified electrospun poly(vinyl alcohol) nanofibrous membranes for glucose oxidase immobilization. Express Polymer Letters, 8, 565-573 (2014).

https://doi.org/10.3144/expresspolymlett.2014.60

[21] Weiser D., Sóti P. L., Bánóczi G., Bódai V., Kiss B., Gellért Á., Nagy Zs. K., Koczka B., Szilágyi A., Marosi G., Poppe L.: Bioimprinted lipases in PVA nanofibers as efficient immobilized biocatalysts. Tetrahedron, 72, 7335-7342 (2016).

https://doi.org/10.1016/j.tet.2016.06.027

[22] Piacentini E., Yan M., Giorno L.: Development of enzyme-loaded PVA microspheres by membrane emulsification. Journal of Membrane Science, 524, 79-86 (2017).

https://doi.org/10.1016/j.memsci.2016.11.008
[23] Gröger H., Capan E., Barthuber A., Vorlop K-D.: Asymmetric synthesis of an $(R)$-cyanohydrin using enzymes entrapped in lens-shaped gels. Organic Letters, 3, 19691972 (2001). https://doi.org/10.1021/ol015920g

[24] Xie W., Zang X.: Immobilized lipase on core-shell structured $\mathrm{Fe}_{3} \mathrm{O}_{4}-\mathrm{MCM}-41$ nanocomposites as a magnetically recyclable biocatalyst for interesterification of soybean oil and lard. Food Chemistry, 194, 1283-1292 (2016).

https://doi.org/10.1016/j.foodchem.2015.09.009

[25] Xie W., Zang X.: Covalent immobilization of lipase onto aminopropyl-functionalized hydroxyapatite-encapsulated- $\gamma-\mathrm{Fe}_{2} \mathrm{O}_{3}$ nanoparticles: A magnetic biocatalyst for interesterification of soybean oil. Food Chemistry, 227, 397-403 (2017).

https://doi.org/10.1016/j.foodchem.2017.01.082

[26] Németh Cs., Gyarmati B., Abdullin T., László K., Szilágyi A.: Poly(aspartic acid) with adjustable pH-dependent solubility. Acta Biomaterialia, 49, 486-494 (2017). https://doi.org/10.1016/j.actbio.2016.11.065

[27] Wang B., Jeon Y. S., Bhang S. H., Kim J-H.: Bioinspired dopamine-conjugated polyaspartamide as a novel and versatile adhesive material. Express Polymer Letters, 11, 601-610 (2017).

https://doi.org/10.3144/expresspolymlett.2017.58

[28] Gyarmati B., Mészár E. Zs., Kiss L., Deli M. A., László K., Szilágyi A.: Supermacroporous chemically crosslinked poly(aspartic acid) hydrogels. Acta Biomaterialia, 22, 32-38 (2015).

https://doi.org/10.1016/j.actbio.2015.04.033

[29] Roweton S., Huang S. J., Swift G.: Poly(aspartic acid): Synthesis, biodegradation, and current applications. Journal of Environmental Polymer Degradation, 5, 175-181 (1997). https://doi.org/10.1007/BF02763661

[30] Krisch E., Gyarmati B., Szilágyi A.: Preparation of pHresponsive poly(aspartic acid) nanogels in inverse emulsion. Periodica Polytechnica Chemical Engineering, 61, 19-26 (2017). https://doi.org/10.3311/PPch.9788

[31] Szilágyi B. Á., Gyarmati B., Horvát G., Laki Á., BudaiSzücs M., Csányi E., Sandri G., Bonferoni M. C., Szilágyi A.: The effect of thiol content on the gelation and mucoadhesion of thiolated poly(aspartic acid). Polymer International, 66, 1538-1545 (2017). https://doi.org/10.1002/pi.5411

[32] Molnar K., Jedlovszky-Hajdu A., Zrinyi M., Jiang S., Agarwal S.: Poly(amino acid)-based gel fibers with $\mathrm{pH}$ responsivity by coaxial reactive electrospinning. Macromolecuar Rapid Communications 38, 1700147/11700147/5 (2017).

https://doi.org/10.1002/marc.201700147 
[33] Molnar K., Juriga D., Nagy P. M., Sinko K., JedlovszkyHajdu A., Zrinyi M.: Electrospun poly(aspartic acid) gel scaffolds for artificial extracellular matrix. Polymer International, 63, 1608-1615 (2014).

https://doi.org/10.1002/pi.4720

[34] Krisch E., Gyarmati B., Barczikai D., Lapeyre V., Szilágyi B. Á., Ravaine V., Szilágyi A.: Poly(aspartic acid) hydrogels showing reversible volume change upon redox stimulus. European Polymer Journal, 105, 459-468 (2018).

https://doi.org/10.1016/j.eurpolymj.2018.06.011

[35] Boros Z., Weiser D., Márkus M., Abaháziová E., Magyar Á., Tomin A., Koczka B., Kovács P., Poppe L.: Hydrophobic adsorption and covalent immobilization of Candida antarctica lipase B on mixed-function-grafted silica gel supports for continuous-flow biotransformations. Process Biochemistry, 48, 1039-1047 (2013). https://doi.org/10.1016/j.procbio.2013.05.002

[36] Krisch E., Messager L., Gyarmati B., Ravaine V., Szilágyi A.: Redox- and pH-responsive nanogels based on thiolated poly(aspartic acid). Macromolecular Materials and Engineering, 301, 260-266 (2016).

https://doi.org/10.1002/mame.201500119
[37] Vlasák J., Rypáček F., Drobník J., Saudek V.: Properties and reactivity of polysuccinimide. Journal of Polymer Science: Polymer Symposia, 66, 59-64 (1979). https://doi.org/10.1002/polc.5070660109

[38] Chen C. S., Fujimoto Y., Girdaukas G., Sih C. J.: Quantitative analyses of biochemical kinetic resolutions of enantiomers. Journal of the American Chemical Society, 104, 7294-7299 (1982).

https://doi.org/10.1021/ja00389a064

[39] Thommes M., Kaneko K., Neimark A. V., Olivier J. P., Rodriguez-Reinoso F., Rouquerol J., Sing K. S. W.: Physisorption of gases, with special reference to the evaluation of surface area and pore size distribution (IUPAC Technical Report). Pure and Applied Chemistry, 87, 1051-1069 (2015) https://doi.org/10.1515/pac-2014-1117

[40] Paravidino M., Sorgedrager M. J., Orru R. V. A., Hanefeld U.: Activity and enantioselectivity of the hydroxynitrile lyase MeHNL in dry organic solvents. Chemistry - A European Journal, 16, 7596-7604 (2010). https://doi.org/10.1002/chem.201000487 